\title{
HYPOCALCAEMIC TETANY AND METHAEMALBUMINAEMIA IN ACUTE FULMINATING PANCREATITIS
}

\author{
A. J. WeBB, F.R.C.S. \\ Senior Surgical Registrar, Queen Elizabeth Hospital, Birmingham 15
}

ACUTE pancreatitis still presents diagnostic difficulty. Fallis in 1937 recorded a correct pre-operative diagnosis in only five of $\mathbf{3 2}$ cases. Burnett and Ness (1955) noted that 14 of their series of 24 cases were diagnosed at laparotomy, while in a recent series of roo cases from Leeds (Pollock, 1959) 35 were incorrectly diagnosed until laparotomy and a further nine unrecognized until autopsy. Considerable assistance may be obtained from the serum calcium level and the presence of circulating methæmalbumin, biochemical estimations of value in both diagnosis and prognosis. Though Edmondson and Berne (1944) emphasized the value of serum calcium estimations, and their work has been confirmed by others (Lipp, 1946; Gambill, Baggenstoss, Van Patter and Power, 1948; Bockus, Kalser, Roth, Bogoch and Sten, 1955), this investigation is still infrequently used, so that in several subsequent series (Paxton and Payne, 1948; Taylor, 1949; Siler, Wulsin and Carter, 1955; Sinclair, 1959) it has received scant attention. In the following acute fulminating case (Deaver, 1921; Eliason and North, 1930) both investigations proved valuable.

\section{Case Report}

A married woman of 62 years was admitted to the Birmingham General Hospital under the care of Mr. George Watts at 8 p.m. on 2.12.6r.

Following a normal light breakfast ten hours before admission, she had experienced a moderately severe epigastric pain of sudden onset, rapidly worsening. The pain became generalized, spreading particularly to the lower abdominal quadrants and interscapular region. Vomiting of small amounts of brownish fluid began soon after the pain and recurred several times throughout the day. Her condition deteriorated and she had failed to pass urine since the onset of the pain. For four years she had had irregularly occurring attacks of abdominal discomfort $\mathrm{I}$ hour after meals and relieved only by sodium bicarbonate. In 1958 she was thought to have suffered an attack of acute cholecystitis; however, a low fat diet was prescribed and for a year her indigestion improved, though it returned late in 1959.

She was pale, ill and 'shocked' with cool extremities, lying restlessly on the couch propped up with her knees flexed, retching small amounts of fluid. Pale mucosæ were noted but no cyanosis or icterus. Temperature $97^{\circ} \mathrm{F}$., pulse rate $84 / \mathrm{min}$., regular rhythm, BP 100/60 $\mathrm{mm}$. $\mathrm{Hg}$; all peripheral pulses were present and the cardiovascular system was normal; the lung bases were clear of râles. With generalized tenderness and guarding, particularly in the lower quadrants, no masses were palpable and liver dullness was present on percussion; no bowel sounds were heard. Turning the patient on to her left side produced a severe exacerbation of pain in the back and upper abdomen. On rectal examination there was tenderness throughout the pouch of Douglas. The differential diagnosis was considered to be either a perforated peptic ulcer or acute pancreatitis; although the abdominal signs seemed unusually severe for a pancreatitis of 10 hours' duration, yet the other features were more in keeping with this. An erect film of the abdomen indicated no free subdiaphragmatic gas but a collection of opacities suggestive of gall-stones. The diagnosis of acute pancreatitis was confirmed by a serum amylase level of 8,000 Somogyi units/100 ml. (normal range 60 to 120 units/100 ml.). Intravenous fluids and gastric suction were begun and pethidine, $100 \mathrm{mg}$., with atropine, $0.6 \mathrm{mg}$., were given intramuscularly. Though $110 / 70 \mathrm{~mm}$. Hg. at 9.30 p.m., the blood pressure had fallen to $80 / 60 \mathrm{~mm}$. Hg. six hours later, when the patient complained of feeling dizzy with a tingling sensation around the lips and tightness in the hands associated with thirst. She was more shocked than on admission; Chvostek and Trousseau's signs were positive.

Plasma (550 $\mathrm{ml}$.) was given within ro minutes together with $20 \mathrm{ml}$. of $10 \%$ calcium gluconate and $100 \mathrm{mg}$. of hydrocortisone hemisuccinate; the tetanic manifestations quickly cleared. Intensive supportive therapy was continued, including whole blood, further hydrocortisone hemisuccinate and noradrenaline. The subsequent clinical course was one of progressive deterioration with severe oliguria. Positive Chvostek and Trousseau's signs together with peri-oral tingling were manifest at intervals throughout $3.12 .6 \mathrm{I}$ and in the early hours of 4.12.6r. Further calcium gluconate was given with immediate relief of tetanic symptoms and signs. She lapsed into coma at 3 a.m. 4.12.6r and died at 7 a.m. 4.12.6r, 70 hours after the onset of symptoms.

Investigations.

2.12.6I: Hb 90\%; serum amylase (Somogyi) 8,000 units/100 ml., serum bilirubin $1.2 \mathrm{mg}$./100 ml., methæmalbumin - trace, haptoglobin-normal level.

3.12.6r: Serum amylase (Somogyi) 6,000 units/100 ml., serum bilirubin $0.9 \mathrm{mg}$./ $100 \mathrm{ml}$., serum calcium (4 a.m.) $6.2 \mathrm{mg}$./ $100 \mathrm{ml}$., methæmalbumin-strongly positive, haptoglobin-trace.

5.I2.61: The amylase level of the peritoneal fluid obtained post-mortem was 25,000 units (Somogyi)/roo $\mathrm{ml}$. The fluid contained hæmoglobin, methæmoglobin and methæmalbumin.

\section{Autopsy Report (Dr. W. H. S. George)}

At autopsy, carried out 5 hours after death, the body was that of a sparely-built woman, the abdomen was distended, Grey Turner's sign was present in the flanks and at the umbilicus, and there were 5 pints of bloodstained fluid in the peritoneal cavity. Abundant fat necrosis was present, particularly in the omentum and pouch of Douglas. Extensive blood nlot surrounded the tail of the pancreas, splenic hilum and upper pole of the left kidney and was contained in the lesser sac. There was hæmorrhagic necrosis of the pancreas, particularly along the lower border. Extensive necrosis of the tail was noted together with surrounding fat necrosis.

The gall bladder was not thickened but contained numerous pigment stones; the common bile duct was 
normal and free of stones. In the lungs emphysema and early basal bronchopneumonia present. Histological examination confirmed extensive hæmorrhagic necrosis of the pancreas.

\section{Discussion}

The literature on hypocalcæmia and pancreatic necrosis is not extensive. The earliest reports of acute pancreatitis and tetany came from the Continent and Japan (Bertelsmann, 1927; Cibert and Pauchu, 1933; Amano and Murata, 1936); in none of these was hypocalcæmia considered to be a factor. Edmondson and Fields in 1940 postulated that the cause of the tetany was hypocalcrmia and they quoted a calcium level of $7.5 \mathrm{mg}$. $/ \mathrm{r} 00 \mathrm{ml}$. in the abdominal transudate collected at autopsy. Further papers (Edmondson and Fields, 1942; Edmondson and Berne, 1944) followed and in 1944 Trevor and Brown first demonstrated the association between hæmorrhagic pancreatitis, tetany and hypocalcæmia. Edmondson and Berne (r944) stated that a serum level below $7 \mathrm{mg}$./100 ml. was indicative of a fatal issue, while Lipp (1946) first emphasized the diagnostic value of serum calcium levels. More recent papers (Pollock, I959; Bockus, 1955) have confirmed both these aspects.

The hypocalcæmia is generally thought to be due to the large amount of calcium which may be fixed or dislocated in the fat necrosis (Edmondson and Fields, I940 and 1942). Gambill and others (1948) found this hypothesis incomplete and considered that calcium was also lost in the peritoneal exudate; a case quoted by Edmondson, Berne, Homann and Wertmann (1952) would support this. The patient was given 4,700 $\mathrm{mg}$. of calcium intravenously, but the serum level rose from $5.9 \mathrm{mg}$. to $8.8 \mathrm{mg}$. $/ \mathrm{r}$ oo $\mathrm{ml}$. only. The maximum amount of calcium extracted from fat necrosis at autopsy was between 1,700 and 2,000 $\mathrm{mg}$. The tardy response of the parathyroids and skeletal calcium in restoring the serum level is another interesting feature; an average restorative time of nine days has been suggested.

The exact mechanism of the tetany is still uncertain, but in all instances it responds to intravenous calcium gluconate, although correlation between the presence of tetany and degree of hypocalcæmia is poor (Amano and Murata, r936; Turner Warwick, 1956). Sullens and Lichtenstein (I95I), although presenting no figures of calcium levels, stated that hypokalæmia and hypocalcæmia can co-exist in acute hæmorrhagic disease and if hypokalæmia alone is corrected then tetany may be precipitated in view of the antagonistic effects of $\mathrm{K}^{+}$and $\mathrm{Ca}^{++}$on neuromuscular irritability.

Gambill and others (1948), commenting on the tetany, note that both hypokalæmia and hypoproteinæmia (McClean and Hastings, 1935) would counteract the effect of hypocalcæmia. It is interesting to note that in a series of 27 cases studied biochemically (Edmondson and Berne, r952) in five fatal cases where the serum calcium level was below $7 \mathrm{mg} . / \mathrm{r}$ oo $\mathrm{ml}$., severe shock and oliguria were associated with hyperkalæmia; tetany would be more likely under such circumstances. Hypo calczmia occurs most commonly between the thir to eleventh days; perhaps more cases would exhibiz tetany in the latter part of this period but for th hypokalæmia and hypoproteinæmia, which may. have had time to develop.

Hypocalcæmia and tetany are rarely encountere $\overline{\bar{\phi}}$ in emergency abdominal conditions, although there are a few Continental references to tetany witio gangrenous cholecystitis and acute intestinal ob struction (Melchior, 1923; Bircher, 1913; Aman® and Murata, 1936) without evidence of hypo $\frac{0}{2}$ calcæmia. One case is known to the author of tetany associated with severe hypokalæmia present $\overrightarrow{0}$ ing in a jejunal obstruction of seven days' duration:In typical cases of acute pancreatitis the serum calcium level is a good indication of the severity of the condition and the likely prognosis, especially tetany occurs within the first 48 hours with a serung. level below $7 \mathrm{mg}$./ $100 \mathrm{ml}$. Exception to this will occasionally occur (Turner-Warwick, 1956). In the reported cases the clinical manifestations of tetanf were never complete: sometimes carpal spasm appeared alone, sometimes only Trousseau's sign laryngismus stridulus was never observed.

A recent case report from the Massachusetts General Hospital (Case Records, r96I) re-eme phasized the diagnostic difficulty which may arise The serum calcium level is of great value in this respect. In very severe fulminating cases the serumb amylase level may be normal due to rapid destrifco tion of secreting tissue, but the serum calcium be low. Similarly, in a milder case admitted sevefá days after the onset, with a bizarre clinical picture perhaps suggestive of pancreatitis, the serumo amylase may have returned to normal; however: hypocalcæmia may still be present.

The presence of circulating methæmalbumin has recently claimed attention (Mazumdar, I961은 Northam, Rowe and Winstone, 1962). Edmondson and others (I 952) recorded two fatal cases of sever shock, renal failure, oliguria and hyperkalæmia in: which the serum was noted to be brown in colour? Subsequent histology revealed tubular necrosis an pigment casts of possibly hæmoglobinuric origin $\frac{O}{3}$ although in neither the serum nor the casts was the pigment identified. Mazumdar's case was of fatal hæmorrhagic pancreatitis and she could finc no previous report of its association with methæmale bumin. A subsequent communication (Northam and others, I962) presented six out of a series of 12 cases where methæmalbumin was confirmed b\%: spectroscopic and electrophoretic estimations using methods previously reported (Neale, Aber an Northam, 1958). All the cases were of hæmorrhagif disease confirmed at laparotomy or necropsy; onlyw one of the six survived. They considered that? as haptoglobin was present in the serum in alb their cases, the origin of the methæmalbumin was్ not due to intravascular hæmolysis. The mose likely explanation, given by Mazumdar, is that hæmatin is formed from liberated hæmoglobin ir the hæmorrhagic peritoneal fluid. Absorption int $\Phi$ the circulation accounts for the conjugation witlo 
albumin and the serum methæmalbumin. As methæmalbumin has not been detected in ectopic gestation, perforated peptic ulcer or hæmorrhagic conditions where hæmoglobin is liberated, Northam and others (1962) conclude that pancreatic enzymes are necessary for its production, and if this is so the test should be specific for hæmorrhagic pancreatitis. Both papers agree that the presence of methæmalbumin indicates severe, probably fatal, hæmorrhagic disease; it may well be an indication of circulating proteolytic products (Rush and Cliffton, 1952). On 3.12.6I, when the serum methæmalbumin in this case was strongly positive, only a trace of haptoglobin was present. A probable explanation (Northam, 1962, personal communication) is not that intravascular hæmolysis had taken place, but that, due to intraperitoneal bleeding (recognizable blood clot was found at autopsy), hæmoglobin as well as hæmatin was absorbed.

The hypocalcæmia and methæmalbuminæmia in this patient confirmed the exact nature of the diagnosis and indicated a fatal outcome. No other recorded case of proved hypocalcæmic tetany within 24 hours of the onset has been found.

\section{Summary}

A case is presented of a woman with severe hæmorrhagic pancreatitis; a very high serum amylase level associated with tetanic signs within 24 hours of the onset was noted. Serum calcium estimations confirmed hypocalcæmia.

No confirmed case of such severity has been found in the literature.

A review of the hypocalcæmic aspect of pancreatitis is set out with a short discussion on the occurrence of tetany in this state.

The presence of methæmalbuminæmia is discussed.

The diagnostic and prognostic value of these features is emphasized.

I wish to thank Mr. George T. Watts for permission to publish this case, Professor Bryan N. Brooke for advice during its preparation, and Mr. T. Dee for photographic assistance.

\section{REFERENCES}

Amano, M., and Murata, M. (1936): Tetany with Acute Abdominal Diseases, Zbl. Chir., 63, 694.

Bertelsmann, R. (1927): Post-operative Tetany with Acute Suppurative Cholecystitis and Acute Pancreatic Necrosis, Ibid., 54, 324 .

Bircher, R. (I913): Tetany and Acute Gangrenous Cholecystitis, Ibid., 40, I659.

Bockus, H. L., Kalser, M. H., Roth, J. L. A., Bogoch, A. L., and Stein, G. (1955): Clinical Features of Acute Inflammation of the Pancreas, Arch. intern. Med., 96, 308.

Burnett, W., and Ness, T. D. (I955): Serum Amylase and Acute Abdominal Disease, Brit. med. F., ii, 770.

CiberT, J., and PAUCHU, M. (1933): Hæmorrhagic Pancreatic Disease and Tetany, Lyon méd., 152, 587.

Deaver, J. (192 I): Pancreatitis, Surg. Clin. N. Amer., i, I.

Edmondson, H. A., and Berne, C. J. (1944): Calcium Changes in Acute Pancreatic Necrosis, Surg. Gynec. Obstet., 79, 240.

, Homann, R. E., Jr., and Wertman, M. (1952): Calcium, Potassium, Magnesium and Amylase Disturbances in Acute Pancreatitis, Amer. F. Med., 12, 34.

- and FIELDS, I. A. (1940): Calcium in Acute Pancreatic Necrosis, Proc. Soc. exp. Biol. (N. Y.), 45, 803.

- (1942): Relation of Calcium and Lipids to Acute Pancreatic Necrosis, Arch. intern. Med., $69,177$.

Eliason, E. L., and North, J. P. (1930): Acute Pancreatitis, Surg. Gynec. Obstet., 51, 183.

Fallis, L. S. (1937): Cullen's Sign in Acute Pancreatitis, Ann. Surg., ro6, 54.

Gambill, E. E., Baggenstoss, A. H., Vanpatter, W. G., and Power, M. H. (1948): Acute Hæmorrhagic Pancreatitis, Gastroenterology, II, 37I.

Lipp, W. F. (1946): Acute Pancreatitis. Report of a Case showing Serum Calcium Changes as well as a Grey Turner's Sign, Ibid., 7, 569 .

Massachusetts General Hospital Case Records (1961): Weekly Clinico-pathological Exercises, New Engl. F. Med., 265, 696.

MAZUMDAR, P. M. H. (196r): A Case of Acute Pancreatitis with Methæmalbuminæmia, Brit. med. F., ii, 1617.

MELCHIOR quoted by BERTELSMANN (1927).

McLean, F. C., and Hastings, A. B. (1935): The State of Calcium in the Fluids of the Body, F. biol. Chem., ro8, 285.

Neale, F. C., Aber, G. M., and Northam, B. E. (1958): The Demonstration of Intravascular Hæmolysis by Means of Serum Paper Electrophoresis and a Modification of Schumm's Reaction, $\mathcal{F}$. clin. Path., II, 206.

Northam, B. E., Rowe, D. S., and Winstone, N. E. (1962): Acute Pancreatitis with Methæmalbuminæmia (Letter), Brit. med. F., i, 260.

(1962): Personal communication.

Paxton, J. R., and Payne, J. H. (1948): Acute Pancreatitis, Surg. Gynec. Obstet., 86, 69.

Pollock, A. V. (r959): Acute Pancreatitis, Brit. med. F., i, 6.

Rush, B. J., Jun., and Cliffton, E. E. (1952): Role of Trypsin in the Pathogenesis of Acute Hæmorrhagic Pancreatitis and the Effect of Antitryptic Agents in Treatment, Surgery, 3r, 349.

Siler, V. E., Wulsin, J. E., and CARTER, B. N. (1955): Important Clinical Factors of Acute Pancreatitis, Surg. Gynec. Obstet., 100, 357.

SINCLAIR, I. R. S. (1959): Acute Pancreatitis-Primary and Postoperative, f. roy. Coll. Surg., Edinb., $5,57$.

Sullens, W. E., and Lichtenstein, M. E. (1951): Acute Pancreatitis, Diagnosis and Treatment, Ann. Surg., r34, 853.

TAYloR, R. A. R. (1949): Acute Pancreatitis, Ann. roy. Coll. Surg., Engl., 5, 213.

Trevor, W., and Brown, L. (1944): Acute Pancreatitis Complicated by Tetany, $\mathscr{Y}$. Amer. med. Ass., 125, 27.

TURNER-WARWICK, R. T. (1956): Hypocalcæmia in Acute Pancreatitis, Lancet, ii, 546. 